\title{
EFFECT OF ONLINE BUYING EXPERIENCE ON CUSTOMER LOYALTY
}

\author{
By \\ Kurniawan Yunus Ariyono ${ }^{1}$, Sukma Irdiana ${ }^{2}$, Kusnanto Darmawan ${ }^{3}$ \\ 1,2,3 ITBWidya Gama Lumajang \\ Email: ${ }^{1}$ ariyonoary45@gmail.com
}

\begin{tabular}{|c|c|}
\hline Article Info & ABSTRACT \\
\hline Articlehistory: & This study aims to determine and analyze how far the buying experience can affect \\
\hline Received Nov 13, 2021 & the loyalty of Traveloka Online Experience users. This study uses the independent \\
\hline Revised Dec 28, 2021 & variable $(X)$ namely online buying experience and the dependent variable $(Y)$ namely \\
\hline Accepted Jan 16, 2021 & customer loyalty. The population of this study is all consumers who use Traveloka \\
\hline & $\begin{array}{l}\text { Online Experiance in the city of Surabaya. Sampling was carried out using the Non } \\
\text { Probability Sampling technique with the Purposive Sampling method. The criteria }\end{array}$ \\
\hline Keywords: & for determining the sample used in this study are as follows: Users who have used \\
\hline Online Buying Experience, & Traveloka Online Experience for more than 3 months. With a sample of 100 \\
\hline Customer Loyalty & $\begin{array}{l}\text { results obtained from this study indicate that the experience of buying online greatly } \\
\text { affects consumers' loyalty to a product or service. This is evident from the trust and } \\
\text { satisfaction of consumers for the product or service purchased. So that consumers } \\
\text { will indirectly introduce the product to others. }\end{array}$ \\
\hline
\end{tabular}

Thisisan open accessarticleundertheCC BY-SAlicense.

CorrespondingAuthor:
Kurniawan Yunus Ariyono,
ITBWidya Gama Lumajang,
Email: ariyonoary45@gmail.com

\section{INTRODUCTION}

Currently, there are more and more e-commerce players or market places selling various flagship promos. One of them is by attracting consumers through various interesting shopping experiences such as through certain games. When compared to consumers abroad, consumers in Indonesia are very influenced by consumer engagement or how these actors can place their consumers as close as possible. Consumers in Indonesia shopping is not just shopping, but as an experience in exploring the online world. Therefore, entertainment and game features in shopping applications that can be inserted into the lure of vouchers and other attractive offers are one way to attract consumers with a wider market (Nirawati et al., 2020)[1].

This phenomenon that occurs states that good products and services have not been able to satisfy customers. But now the buying experience is able to evoke a customer sensation in customer loyalty for a product. A consumer loyalty to a product or brand will be formed if the business entity is able to form and create a quality product. It is hoped that by forming and creating a quality product, it will be able to form and create a satisfaction and confidence in consumers towards the product or brand that has been purchased, used, or consumed. The formation and creation of a satisfaction and trust in the end is expected to be able to form and create a loyalty (Panjaitan et al., 2016) [2].

Traveloka Online Experience answers the current phenomenon, where Traveloka customers, who are the majority of business people in Indonesia, are greatly helped by the menu provided by Treveloka. Traveloka Online Experience is a new product from a business unit that focuses on lifestyle. Traveloka Online Experience is designed to encourage users to stay active and hone their skills in the new normal. Traveloka Online Experience not only helps adapt to the current situation but also helps industry players in the creative economy sector. With the Traveloka Online Experience, it is hoped that Traveloka customers or users can be more pampered with this program.

This can form satisfaction, trust and loyalty to customers and other consumers who use Traveloka. Because a satisfaction and trust occurs when a consumer is really satisfied with the experience experienced repeatedly from using the same product or brand, and the consumer assumes that the product or brand will not disappoint him 
(Suntoro\&Silintowe, 2020)[3]. Trust is built, created, or formed because of the expectation that the other party will act in accordance with the wishes and needs of consumers. When someone has trusted the other party, then they will be sure that their expectations will be fulfilled and will not be disappointed (Arizona, 2020)[4]. A person's trust is not only always aimed at fellow humans but also aimed at intangible objects such as brands. If a consumer has believed in a brand, then the consumer will believe that the brand will be able to meet their needs, desires, and expectations. A consumer who has believed in a brand, then the consumer can be said to have bought or often bought or consumed products from that brand, and products for that brand are able to create and shape a good and positive experience. A trust from consumers in a brand can be a positive, profitable, and potential thing as an important target to achieve, because the continuity or existence of the company or the product of the company is very dependent on consumer trust (Supertini et al., 2020)[5].

Based on the existing phenomena, the purpose of the study is to find out and analyze how far the buying experience can affect the loyalty of Traveloka Online Experience users.

\section{LITERATURE REVIEW}

\section{Customer Loyalty}

According to Yulia (2018)[6], customer loyalty is a customer's commitment to persist in depth to re-subscribe or re-purchase a selected product or service consistently in the future, even though the influence of the situation and marketing efforts has the potential to cause behavior change. Meanwhile, according to Supertini et al. (2020) [5] say that customer loyalty is a customer's commitment to a store brand, or supplier, based on a very positive attitude and is reflected in consistent repeat purchases.

According to Hidayat (2012:103)[7] consumer loyalty is a consumer's commitment to a market based on a positive attitude and is reflected in consistent repeat purchases. The indicators of consumer loyalty are:

1. Trust is a response to consumer confidence in the market, namely by not switching to other products

2. Emotion commitment is a psychological commitment of consumers to the market and becomes the main priority for consumers

3. Recommendations are consumer attitudes that suggest other consumers

4. Can use the facilities provided as well as possible

\section{Online Buying Experience}

Theresia \& Wardana (2019)[8] argues that an individual's response in judging is based on three aspects, namely the amount of experience, context or background, and a person's past stimuli. Online shopping is a relatively new activity for various consumers, online purchases are still considered riskier than terrestrial ones (Yin \& $\mathrm{Xu}$, 2021)[9]. Therefore, online shopping consumers will rely heavily on the quality of the experience, where the quality of the experience can be obtained only through previous purchase experiences. According to Slamet et al. (2021)[10] the determinants of the online buying experience consist of four factors, namely:

1. Experienced in online shopping

2. Feel competent when shopping online

3. Feel comfortable when using web shopping

4. Feel that the online site is easy to use

Previous experience will greatly influence future behavior. In the context of online shopping, customers evaluate their online purchasing experience based on perceptions regarding product information, forms of payment, delivery terms, services offered, risks involved, privacy, security, personalization, visual appeal, navigation, entertainment and enjoyment (Afrashteh et al. ., 2014)[11].

\section{METHODS}

The population of this study is all consumers who use Traveloka Online Experiance in the city of Surabaya. According to Sugiyono (2017)[12], the sample is part of the number and characteristics of the population. The sample of this study is part of the population taken as a data source. The sample size is a minimum of 5 times the parameter estimate. If the estimated parameters are 20, then the minimum number of samples is 100 (Hair et al., 2010)[13]. Based on this opinion, the number of samples needed is: 5 times the number of parameters $=5 \times 50=100$ respondents. Sampling is carried out using the Non Probability Sampling technique with the Purposive Sampling method. According to Sugiyono (2017)[12], the purposive sampling method is a sampling technique based on certain criteria or considerations. The criteria for determining the sample used in this study are as follows: Users who have used Traveloka Online Experience for more than 3 months. Considering that the average Traveloka Online Experinace user is the upper middle class, the researchers targeted samples from students to workers and entrepreneurs. Methods of data analysis in this study using descriptive analysis, hypothesis testing using regression analysis. 


\section{RESULTS AND DISCUSSION}

The purpose of the validity test is to measure the validity or validity of a questionnaire. A questionnaire is said to be valid if the questions on the questionnaire are able to reveal something that will be measured by the questionnaire (Sugiyono, 2017)[12]. A questionnaire is declared valid if the question or statement on the questionnaire is able to reveal something that will be measured on the questionnaire. Testing the validity by comparing the product moment index ( $\mathrm{r}$ count) with its critical value. The results of the validity test of all question items for each variable were declared valid.

Reliable means that when used several times to measure the same object, it will produce the same data (Sugiyono, 2017)[12]. The reliability test was tested using Cronbach Alpha. Cronbach Alpha is calculated in terms of the average intercorrelation between items measuring the concept. The results of the reliability test showed that all the variables in this study were reliable.

The purpose of linearity test is to determine the relationship between the independent variable and the dependent variable is linear or not. The criteria for linearity testing are if the significance value is less than 0.05 then the relationship between the independent variable and the dependent variable is linear. The results of the linearity test in the table above can be seen that all variables have a significance value less than 0.05 (sig < 0.05 ), this indicates that all research variables are linear.

Hypothesis testing in this study uses regression analysis with the help of SPSS version 20 software. The basis for testing the hypothesis in this study is to see the results of $t$ count and its significance. The hypothesis is accepted if the value of $t$ count is greater than $t$ table and the significance level has been determined. The summary of the results of hypothesis testing is presented in table 1 below:

Table 1. Hypothesis Test

\begin{tabular}{|c|c|c|c|}
\hline Hypothesis & t Count & Sig. & Description \\
\hline $\begin{array}{ll}\text { Online } & \text { Buying } \\
\text { Experience } & \text { Affects } \\
\text { Customer Loyalty } & \end{array}$ & 4.665 & 0.000 & Hypothesis Accepted \\
\hline
\end{tabular}

Source: SPSS 20 Data Processing, 2021

Based on the results of the hypothesis test above, it can be concluded as follows:

The online buying experience affects the loyalty of Traveloka Online Experience customers, which means that the online buying experience carried out by Traveloka service users is satisfied and believes in Traveloka's credibility. So that Traveloka service users feel loyal to all orders there. This is in line with Garcia et al. (2020)[14], which says that customer loyalty to a product or service is because consumers feel satisfied and believe in the product they have purchased. So that consumers will indirectly repurchase and inform the product to other consumers. Nirawati et.al. (2020)[1] also said that experience is the best teacher in choosing and determining which products are worthy of retaining and repurchasing. In addition, experience also causes consumers to continue and continue to buy because of the belief in the product and the emergence of satisfaction that cannot be described by consumers. So that consumers will indirectly introduce and inform friends or relatives of the advantages of these products.

The experience of Traveloka service users also experienced the same thing as previous research. Where Traveloka consumers or customers feel confident, comfortable, trust and satisfied with the services provided by Traveloka. So that Traveloka customers indirectly, whenever there is an activity or customer desire, directly choose or use Traveloka services. This belief makes Traveloka provide more service by adding new services purchased under the name Online Expriance, where customers are more pampered with more complete facilities and customers just have to choose and place an order according to the expected time. This new facility is one of Traveloka's advantages in pampering its customers.

\section{CONCLUSION}

Based on the results of the study, it was found that the experience of buying a product or service online can make consumers or customers loyal to the product. Loyalty of customers because customers feel satisfied and believe in the products they use. This is what all entrepreneurs must understand, that satisfaction and trust are the spearhead of the success of the product or service that is issued. 


\section{REFERENCE}

[1] L. Nirawati, A. D. Pratiwi, A. Mutiahana, and E. A. Afida, "Pengaruh Kepercayaan Konsumen dan Pengalaman Pelanggan (Custumer Experience) Terhadap Loyalitas Pelanggan pada Aplikasi Shopee," J. Syntax Transform., vol. 1, no. 9, pp. 624631, 2020.

[2] A. O. Y. Panjaitan, Rofiaty, and Sujatmiko, "Pengaruh Pengalaman Merek Terhadap Loyalitas Merek Melalui Mediasi Kepuasan Merek dan Kepercayaan Merek (Studi Pada Kuliner Khas Kota Malang),” J. Bisnis dan Manaj., vol. 3, pp. 141$161,2016$.

[3] W. Suntoro and Y. B. R. Silintowe, "Analisis Pengaruh Pengalaman Merek, Kepercayaan Merek, dan Kepuasan Merek terhadap Loyalitas Merek," Maneggio J. Ilm. Magister Manaj., vol. 32, no. 1, pp. 25-41, 2020, [Online]. Available: http://ojs.uajy.ac.id/index.php/modus/article/view/3194.

[4] A. Arizona, "Analisa Kepercayaan Merek dan Pengalaman Merek Terhadap Loyalitas Konsumen PT. XYZ,” J. Abiwara J. Vokasi Adm. Bisnis, vol. 2, no. 1, pp. 59-72, 2020.

[5] N. P. S. Supertini, N. L. W. S. Telagawati, and N. N. Yulianthini, "Pengaruh kepercayaan dan kepuasan pelanggan terhadap loyalitas pelanggan pada Pusaka Kebaya di Singaraja," Prospek J. Manaj. dan Bisnis, vol. 2, no. 1, p. 61, 2020, doi: 10.23887/pjmb.v2i1.26201.

[6] Y. A. Yulia, "Pengaruh Pengalaman Konsumen Terhadap Loyalitas Konsumen Pada Produk Iphone Dengan Kepuasan Sebagai Variabel Intervening Di Surakarta,” Bhirawa, vol. 3, no. 1, pp. 19-27, 2018, doi: 10.36587/probank.v3i1.304.

[7] Hidayat, Pemasaran Jasa. Malang: Bayumedia Publishing, 2012.

[8] N. M. M. D. Theresia and I. M. Wardana, "Pengaruh Pengalaman Belanja Online, Kepuasan Pelanggan, Dan Adjusted Expection Terhadap Niat Membeli Kembali Melalui Traveloka," E-Jurnal Manaj. Univ. Udayana, vol. 8, no. 8, p. 4899, 2019, doi: 10.24843/ejmunud.2019.v08.i08.p07.

[9] W. Yin and B. Xu, "Effect of online shopping experience on customer loyalty in apparel business-to-consumer ecommerce," Text. Res. J., 2021, doi: 10.1177/00405175211016559.

[10] S. Slamet, F. D. Finalia Sari, I. Indrayati, and I. Azmala, "Millennial Customer Loyalty in Online Shopping on Digital Platforms: a Perspective of Net Promoter Score," J. Bisnis dan Manaj., vol. 22, no. 2, pp. 162-175, 2021, doi: 10.24198/jbm.v22i2.758.

[11] H. Afrashteh, N. Azad, and S. V. Tabatabaei Hanzayy, "The effects of online shopping on the customer loyalty," Manag. Sci. Lett., vol. 4, no. 9, pp. 2077-2086, 2014, doi: 10.5267/j.msl.2014.8.013.

[12] Sugiyono, Metode Penelitian Kuantitatif, Kualitatif, dan R\&D. Bandung: Alfabeta, 2017.

[13] J. F. Hair, W. Black, B. J. Babin, and R. Anderson, Multivariate Data Analysis, 7 Th. New York: Prentice Hall, 2010.

[14] J. M. Garcia, O. B. D. L. Freire, E. B. A. Santos, and J. Andrade, "Factors affecting satisfaction and loyalty to online group buying," Rev. Gestão, vol. 27, no. 3, pp. 211-228, 2020, doi: 10.1108/rege-02-2018-0037. 